\title{
A sudden absence of bees
}

\author{
You've been stung.
}

\begin{abstract}
Nick Mamatas
Enrolment was down. Even the girls with hair down to their hips and lazy smiles know better than to major in literature any more, so the chair had me develop a course to get butts on seats. I took a multidisciplinary approach - English, pol sci, history - to come up with "(Under)mining Consensus Reality: Conspiracy Theories". We read The Da Vinci
\end{abstract} Code and Holocaust on Trial, watched $J F K$, and then the students did a creative final - writing their own conspiracy theories.

I got lots of 9/11 from junior leftists; man-made AIDS from the militant queers and Afrocentric kids; and comical suppositions about UFOs and American Idol from the rest. Except the Front Row: Kap, Julia and Aram. These three bio majors hadn't been in the humanities building since frosh comp, but now they needed a writing-intensive class to graduate and sat together, all quiet intensity and perfectly formatted term papers.

Kap was born in Seoul. In the battle between his adoptive born-again Christian parents and his craving for a seat in Stony Brook's med school, he lost. He wrote "Toward A Postmodern Materialist Buddhism". There is an Intelligent Designer, he argued, despite the fact that humans are remarkably poorly designed. But the Designer lacks experience in limitation and pain. The ID could only experience limitation vicariously, so he makes humanity full of bursting appendices, posterior superior parietal lobes hardwired for religious experience, and with expiration dates. ID theory is sound once one realizes that the ID is a $\mathrm{CT}$ : a Cunning Torturer. I gave Kap a $\mathrm{B}^{+}$: conspiracy theories involve human agency, not a Prime Mover.

Julia was into ecology. Like many outdoorsy girls, she'd developed a great wit to offset her boat hips and mannish chin. "Why Blondes Have More Fun", she wrote. She also got a $\mathrm{B}^{+}$, mainly because she obviously wrote the paper for a bio class, and then tacked on a page of 'natural' conspiracy. A wasp, Hymenoepimecis sp. conspires against the Plesiometa argyra spider. The wasp attacks and lays its eggs within the spider's abdomen. The larva consumes the spider's haemolymph ("spider 'blood'", she explained) and then excretes a chemical that changes the spider's behav- iour. Instead of the web Plesiometa argyra usually builds, the chemical compels the spider to create a box-web design that can support the weight of the pupating wasp. After the web is done, the larva eats the spider, builds a cocoon in the strong web and then pupates.

On the last page of the paper Julia explained that natural blondes secrete a similar chemical when they reach menses. It makes men take blonde girls out to

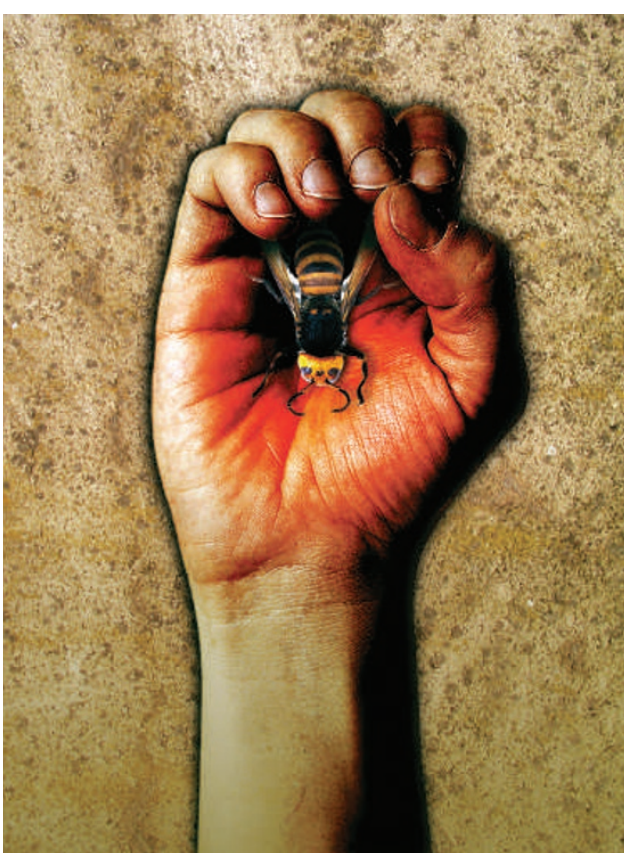

dinner and then, later in life, provide them with houses and cars. Then the men die of early heart attacks due to all the fancy steaks they consumed and the blondes keep the swag. Cute, but I know when a junior is phoning it in.

Aram's theory was "Beepocalypse Now". Producers of genetically modified seeds, he claimed, could create a plant whose pollen would act as a soporific for bees. Rather than returning to their hives, the bees, "dazed and confused for so long" (Aram, all acne and black concert T-shirts, was really into Zep), would just wander off and die. The ecosystem would collapse, allowing agribusiness to monopolize production with GMO crops, which don't need pollination ... for a price. He got a $\mathrm{B}^{+}$as well. The assignment was to write a current event, not a speculative one.

The Front Row weren't happy with their grades, nor with the reasoning I presented during office hours. Then, 18 months later, the bees began to vanish.

This was followed by a rash of church burnings sweeping the United States, and then much of the rest of the world. This wasn't a sectarian strike either; houses of worship of all faiths were targeted. Focus on the Family shut its doors, and in Kansas several former school board members hanged themselves. Pakistan and India began reunification talks and Saudi Arabia witnessed its first ever Pride march, although it ended in violence. Everything ends in violence now.

The kids started demanding more coursework on Nietzsche, and their interpretations of both canonical and postmodern literature got decidedly darker. I drank my way through long nights of grading papers - college writing is almost always bad, but it had never been so twisted. Religiosity hadn't disappeared; instead it warped into a sort of irrational existential angst. Crime and suicide rates skyrocketed. After the latest mass shooting on a college campus, the AAUP demanded an increase in budgeting for distance learning purely for faculty safety.

I realized what was going on while huddled under my desk. The Front Row had done it. The alumni newsletter confirmed my theory. Aram was working on GM crops for the United Nations, and Julia was 'in the field' trying to find the wayward bees. Her 'theory' was that Hymenoepimecis sp. had moved into new ecological niches and crowded them out. Kap was head of a new online faith - the First Virtual Church of Christ the Deleted - that was gaining converts as fast as the world's religions were losing them. They'd proved me wrong.

They couldn't have combined their theories into one bloody actuality just to show me up, could they? That is conspiracy's fallacious attraction. Small cabals don't target history or human events, but theories target the Weltanschauung of their audiences. To deal with the cognitive stress of living we write soothing stories that return us to the centre of the Universe. A malevolent universe is as consoling as a beneficent one. And there is a wasp, the first I've seen in years, trapped between panes of glass in my office window. I don't know how it got there, but I know that I must know. I lift the glass and invite it to sting.

Nick Mamatas is the author of Under My Roof, a novel of neighbourhood nuclear proliferation for children, and other books and stories. He lives near, but not in, Boston, Massachusetts. 